\title{
Platelet monoamine oxidase activity in epilepsy
}

\author{
ZL KRUK, ADRIENNE MOFFETT, AND DF SCOTT \\ From the Department of Pharmacology and Therapeutics, The London Hospital Medical College, and \\ the EEG Department, Section of Neurological Sciences, The London Hospital, London
}

SUMMARY The platelet monoamine oxidase activity (MAO) of 33 patients with epilepsy was compared with a group of neurological patients and a group of normal control subjects. We found that the MAO activity was increased significantly in the epileptic group when compared with the normal. This was not related to anticonvulsant medication. These results could be explained by the effect of epilepsy or anticonvulsant medication on the maturation of platelets.

The role of CNS monoamines in the aetiology of epilepsy is not clear. The incidence of seizures in susceptible individuals when they take tricyclic antidepressants ${ }^{1}$ or when they are treated with monoamine oxidase inhibitors ${ }^{2}$ is strong evidence for such an involvement. The observation that oral tyramine can activate pre-existing episodic EEG abnormalities in epileptic patients ${ }^{3}$, further indicates a possible monoaminergic involvement in this condition. Tyramine is a substance with well-defined indirect sympathomimetic activity, in that it can cause the release and block the re-uptake of noradrenaline and other amines. Tyramine is also a good substrate for monoamine oxidase (MAO), ${ }^{5}$ an enzyme found in platelets which are a readily accessible source of the enzyme in man. One possible explanation of the findings of Swash et $a l^{3}$ is that tyramine metabolism is abnormal in patients with epilepsy, so we have studied MAO activity in platelets from such patients.

\section{Patients and methods}

Three groups were studied. The first group contained 33 patients with epilepsy (16 men and 17 women), average age 35 years. The second group included 22 control neurological patients $(11$ men and 11 women), average age 31 years. Finally, 19 normal control subjects (nine men and 10 women) with an average age of 35 years were studied. The patients with epilepsy all had a long-

Address for reprint requests: Dr DF Scott, EEG Department, Section of Neurological Sciences, The London Hospital, Whitechapel, London E1 1BB.

Accepted 14 June 1979. standing seizure disorder mainly arising in the temporal lobe.

Eight millilitres of venous blood were collected from each subject into tubes treated with EDTA. The blood was then mixed with $8 \mathrm{ml}$ of a solution containing $9 \mathrm{~g} / 1$ of $\mathrm{NaCl}$ and $20 \mathrm{~g} / 1$ of EDTA. The mixture was centrifuged at $1000 \mathrm{~g}$ for 15 min and the platelet rich plasma was carefully removed, avoiding contamination with red blood cells. This plasma was then centrifuged at $2400 \mathrm{~g}$ for $15 \mathrm{~min}$ and the supernatant was discarded. The platelets were then resuspended in $1 \mathrm{ml} 0.3 \mathrm{M}$ sucrose and centrifuged again at $2400 \mathrm{~g}$ for 15 min. The supernatant was carefully aspirated and discarded, and the platelets resuspended in $1 \mathrm{ml}$ $0 \cdot 3 \mathrm{M}$ sucrose, and stored at $-20^{\circ} \mathrm{C}$. The identity of the source of the blood samples was known only to one of us (DFS) who collected them but who did not take part in the purification of the platelets, or in the measurement of enzyme activity.

Platelet MAO activity was measured using kynuramine as substrate ${ }^{6}$. The platelets were gently thawed, and then suspended using a Potter-Elvehjem tissue homogeniser. Duplicate $100 \mu \mathrm{l}$ samples were used for determination of enzyme activity and protein. ${ }^{8}$ The results are expressed as nmoles of product (4-hydroxyquinoline) formed $/ \mathrm{mg}$ of protein $/ 30 \mathrm{~min}$ incubation period.

\section{Results}

The MAO activity of platelets from patients with epilepsy was found to be significantly increased compared with that of normal subjects, and this 
was the case for both men and women (table 1). However, in the epileptic groups as a whole, there were no significant differences in platelet MAO activity when five other parameters were

Table 1 Human platelet $M A O$ activity from male and female subjects. Results are expressed as mean $M A O$ activity (nmoles 4-hydroxyquinoline formed/mg protein/ $30 \mathrm{~min}) \pm S E$ of mean. Number of observations in brackets. Level of significance were assessed using Students $t$ test.

\begin{tabular}{llll}
\hline & All subjects & Women & Men \\
\hline $\begin{array}{l}\text { Epileptic } \\
\text { patients }\end{array}$ & $496.5 \pm 44.3(33) * 583.0 \pm 65(16) \ddagger$ & $415.0 \pm 55.1(17)$ \\
$\begin{array}{l}\text { Neurological } \\
\text { control } \\
\text { patients } \\
\text { Normal } \\
\text { control }\end{array}$ & $440.3 \pm 50.8(20)^{-} 373.5 \pm 68(11)$ & $522.0 \pm 72.1(9)$ \\
subjects & $367.1 \pm 36.2(20)$ & $444.0 \pm 62.4(10)$ & $290.2 \pm 18.2(10) \S \dagger$ \\
\hline
\end{tabular}

* $\mathrm{P}<0.05$ when compared with normal subjects

$+\mathrm{P}<0.05$ when compared with normal women

$\pm \mathrm{P}<0.05$ when compared with neurological control women

$\S \mathrm{P}<0.05$ when compared with neurological control men

examined. The severity of epilepsy, the degree of EEG abnormality, the time since the last fit, or whether high or low levels of anticonvulsant drug were being taken did not seem to be important (table 2).

Table 2 Influences of clinical factors on platelet MAO activity in patients with epilepsy. Results expressed as in table 1

\begin{tabular}{|c|c|}
\hline C!inical factors & Platelet $M A O$ activity \\
\hline $\begin{array}{l}\text { Severe epilepsy } \\
\text { More than one seizure/week } \\
\text { Mild epilepsy } \\
\text { Less than one seizure/week } \\
\text { Marked EEG abnormality } \\
\text { Minimal EEG abnormality } \\
\text { Recent fit (with } 24 \text { h } \\
\text { blood collection) } \\
\text { No recent fit } \\
\text { High daily anticonvulsant dose } \\
\text { (6 units of more) } \\
\text { Low daily anticonvulsant dose } \\
\text { (5 units or less) } \\
\text { All taking anticonvulsants } \\
\text { Not taking anticonvulsants }\end{array}$ & $\left\{\begin{array}{l}421.9 \pm 112.5(7) \\
516.5 \pm 47.9(26) \mathrm{NS} \\
433.5 \pm 77.4(9) \\
520.0 \pm 53.7(24) \mathrm{NS} \\
479.0 \pm 87.7(11) \\
489.4 \pm 58.5(21) \mathrm{NS} \\
492.1 \pm 56.2(21) \\
\\
481.4 \pm 77.8(12) \mathrm{NS} \\
489.3 \pm 43.6(33) \mathrm{NS} \\
403.4 \pm 31.4(41) \mathrm{NS}\end{array}\right.$ \\
\hline
\end{tabular}

Anticonvulsant dosage expressed in units ${ }^{9}$

Considering the patients with neurological conditions other than epilepsy, we found that MAO activity was significantly less than that of epileptic women, though not significantly different from normal women whose enzyme activity was intermediate between the epileptic and neurological groups, but not significantly different from either group.
Platelet MAO was significantly increased in men with neurological conditions other than epilepsy when compared with normal men, which contrasts with similar female groups between whom there was no significant difference. The MAO activity in blood platelets of normal women was significantly greater than that of normal men, who form a particularly homogeneous group.

\section{Discussion}

The importance of increased platelet MAO activity in epileptic patients compared with control subjects is not immediately obvious, especially as the clinical features of the condition do not relate to MAO activity. Our results contrast with those of Shohnori et $a l^{10}$ who found reduced platelet MAO activity in a small number of epileptic patients, but are in agreement as to the lack of association between changes in enzyme activity and seizure intensity, seizure frequency, proximity of last fit, and degree of EEG abnormality. There is no relationship between MAO activity and either the type of anticonvulsant drug used or the dose administered.

The results might be explained in terms of the influence of epilepsy or drugs on either platelet numbers or protein concentration within platelets, as Friedhoff et $a l^{11}$ have shown that variations in human platelet MAO activity may arise because of non-genetically determined variations in these parameters. An alternative explanation might lie in different rates of maturation of platelets or turnover of MAO within platelets, which may occur in epilepsy or as a result of anticonvulsant drugs. Murphy et $a l^{12}$ found that platelet MAO activity varied in different density gradient fractions of platelets, suggesting that size and MAO activity of platelets decrease with age. If it could be shown that epilepsy or anticonvulsant drugs affected the rate of maturation of the platelets, their proteins, or MAO then an explanation of our observations would be at hand.

\section{References}

1 Klerman GL, Cole JO. Clinical pharmacology of imipramine and related antidepressant compounds. Pharmacol Rev 1965; 17:101-41.

2 Shepherd M, Lader M, Rodnight R. Clinical Psychopharmacology. London: English University Press, 1968.

3 Swash M, Moffett AM, Scott DF. Tyramine activates the EEG in epileptic patients. Nature 1975; 258:749-50. 
4 Hertting G, Axelrod J, Patrick R. Action of cocaine and tyramine on the uptake and release of $\mathrm{H} 3 /$ norepinephrine in the heart. Biochem Pharmacol 1961; 8:246-8.

5 Gabay S, Achee FM, Mentes GJ. Some parameters affecting the activity of monoamine oxidase in purified bovine brain mitochondria. Neurochem 1976; 27:415-24.

6 Krajl M. A repeat microfluorimetric determination of monoamine oxidase. Biochem Pharmacol 1965; 14:1684-5.

7 Century B, Rupp KL. Comment on microfluorimetric determination of monoamine oxidase. Biochem Pharmacol 1968; 17:2013.

8 Lowry OH, Rosenbrough NJ, Farr AL, Randall RJ. Protein measurement with Folin-phenol reagent. J Biol Chem 1951; 193:265-75.

9 Richens A, Rowe DJF. Disturbance of calcium metabolism by anticonvulsant drugs. $\mathrm{Br} \mathrm{Med} \mathrm{J}$ 1970; 4:73-6.

10 Shohnori T, Kaneyuki T, Kobayashi K, Mori A, Kohsaka M. Reduced blood platelet monoamine oxidase activity in epileptic patients. IRCS Med Sci Clin Pharmacol Therap 1975; 3:558.

11 Friedhoff AJ, Miller JC, Karpatkin S. Heterogenicity of human platelet. Blood 1978; 51: 317-23.

12 Murphy DL, Costa JL, Shafer B, Corash L. Monoamine oxidase activity in different density gradient fractions of human platelets. Psychopharmacology 1978; 59:193-7. 